\title{
A Case Study on Quality Function Deployment (QFD)
}

\author{
Eshan S. Jaiswal \\ (Mechanical Department, Mewar University, India)
}

\begin{abstract}
Quality Function Deployment (QFD) was conceived in Japan in the late 1960's, and introduced to America and Europe in 1983. This paper will provide a general overview of the QFD methodology and approach to product development. Once familiarity with the tool is established, a real-life application of the technique will be provided in a case study. The case study will illustrate how QFD was used to develop a new tape product and provide counsel to those that may want to implement the QFD process.

Quality function deployment (QFD) is a "method to transform user demands into design quality, to deploy the functions forming quality, and to deploy methods for achieving the design quality into subsystems and component parts, and ultimately to specific elements of the manufacturing process."
\end{abstract}

Keywords: Quality Function Deployment, Tape Product, Product Development, Design Quality, Manufacturing

\section{Introduction}

Quality Function Deployment (QFD) is a quality tool that helps to translate the Voice of the Customer (VoC) into new products that truly satisfy their needs. In this paper, QFD will be reviewed in order to understand how it works, to highlight its strengths and weaknesses and to discuss its practical applications. The first part of the paper will present an overview of QFD and explain the methodology. QFD will be defined and explained by means of an example and a number of benefits and implementation problems will be revealed [1].

First conceptualized in 1966 as a method or concept for new product development under the umbrella of Total Quality Control, Hinshitsu Tenkai (quality deployment) was developed by Dr. Shigeru Mizuno and Yoji Akao. Yoji Akao, et al detailed methods of quality deployment in 1972. The Japan Society of Quality Control formed a research group to specifically study Quality Function Deployment (QFD) in 1978. QFD is used to translate customer requirements to engineering specifications. It is a link between customers - design engineers - competitors - manufacturing. It provides an insight into the whole design and manufacturing operation from concept to manufacture and it can dramatically improve the efficiency as production problems are resolved early in the design phase.

It is very powerful as it incorporates the voice of the customer in the designs - hence it is likely that the final product will be better designed to satisfy the customer's needs. Moreover, it provides an insight into the whole design and manufacturing operation (from concept to manufacture) and it can dramatically improve the efficiency as production problems are resolved early in the design phase.

Quality Function Deployment (QFD) was conceived in Japan in the late 1960' s, and introduced to America and Europe in 1983. During the period between the late 1960's and early 1980's, the concept of QFD was evolved from the belief that Total Quality Control must include not only checking of the control points during production, but an understanding of the requirements prior to the design phase. In the late 1960's, Japanese companies were breaking from their post World War II mode of imitation and copying to a more original mode of product development 1 , making design quality an important consideration. The need to understand the critical design issues prior to production was acknowledged and QC process charts were widely used to ensure that the design criteria were met during manufacturing, but there was no formal system to translate the customer's needs into the initial design and subsequent process control points. Thus, an opportunity was created for QFD to come to fruition as a method to check the design itself for adequacy in meeting customer requirements and to translate those requirements to production [2].

\subsection{When to use QFD:}

QFD is applied in the early stages of the design phase so that the customer wants are incorporated into the final product. Furthermore it can be used as a planning tool as it identifies the most important areas in which the effort should focus in relation to our technical capabilities. Ask yourself these questions:

1. Why do QFD in this case?

2. What will the QFD be made of?

3. Is it the right tool at this time?

4. Is this the right place for implementation?

5. What is the goal and what is success?

6. Who all should we involve? 
1.2 How to use it?

Comprehensive QFD may provide four phases:

1. Product Planning (House of Quality): Translate customer requirement into product technical requirement to meet them.

2. Product Design: Translate technical requirement to key part characteristics or systems.

3. Process Planning: Identify key process operations necessary to achieve key part characteristics.

4. Production Planning (Process Control): Establish process control plans, maintenance plans, training plans to control operations.

Linking these phases provides a mechanism to deploy the customer voice through to control of process operations.

\section{Follow these steps:}

1. Learn what each element represents

2. Form a multidisciplinary team. Obtain voice of the customer from market surveys, focus groups, observations, interviews. Identify customer requirements and ask customer to rate importance.

3. The development of the first issue of the charts is the most time consuming part. Conduct competitive analysis by customer requirement establish a quality plan based on competitive you would like to have for your future product.

Once this is completed regular reviews and updates require minimum time. Remember that the benefits from an appropriately developed QFD chart are very big compared with the effort - put focus on the issues that are important to the customer.

Benefits of QFD include better understanding of customer demands and design interactions; early manufacturing involvement during the design process reducing iterations and focusing the design while fostering teamwork [4].

\section{QFD Methodology And The House Of Quality (HoQ)}

The concept of QFD was created in Japan in the late 1960s. According to Akao (1997) after World War II, Japanese companies used to copy and imitate product development; nevertheless, they decided to move their approach to one based on originality. QFD was introduced, in that environment, as a concept for new product development. It can be better understood from the definition presented below which summarises the purposes of the technique: "QFD is a method for structured product planning and development that enables a development team to specify clearly the customer's wants and needs, and then to evaluate each proposed product or service capability systematically in terms of its impact on meeting those needs"(Cohen, 1995).

The QFD method includes building one or more matrices known as 'quality tables.' The first matrix is named the "House of Quality" (HoQ). It exhibits the customer's needs (VoC) on the left hand side, and the technical response to meeting those needs along the top. Figure 1(a) shows each of the sections contained in the HoQ. Every section holds important data, specific to a part of the QFD analysis. The matrix is usually completed by a specially formed team, who follow the logical sequence suggested by the letters A to F, but the process is flexible and the order in which the HOQ is completed depends on the team [1].

A four phases approach is accomplished by using a series of matrixes that guide the product team's activities by providing standard documentation during product and process development (Figure below). Each phase has a matrix consisting of a vertical column of "Whats" and a horizontal row of "Hows". "Whats" are CR; "Hows" are ways of achieving them. At each stage, the "Hows" are carried to the next phase as "Whats" [4]. 


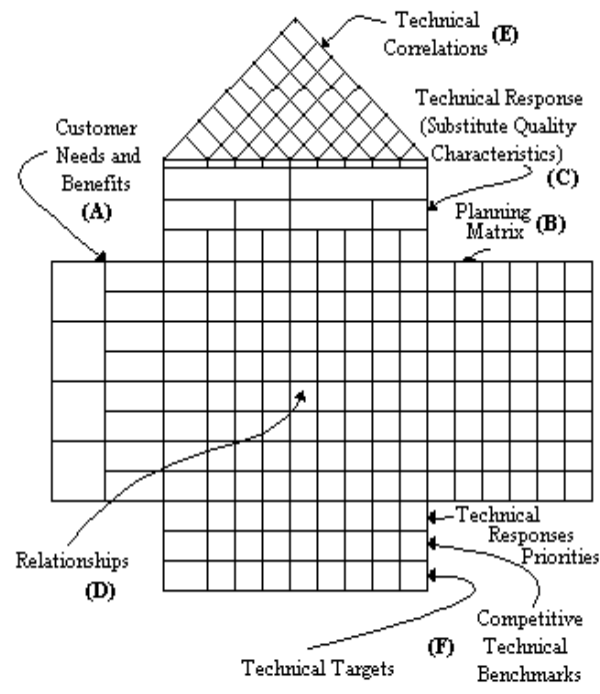

(a)

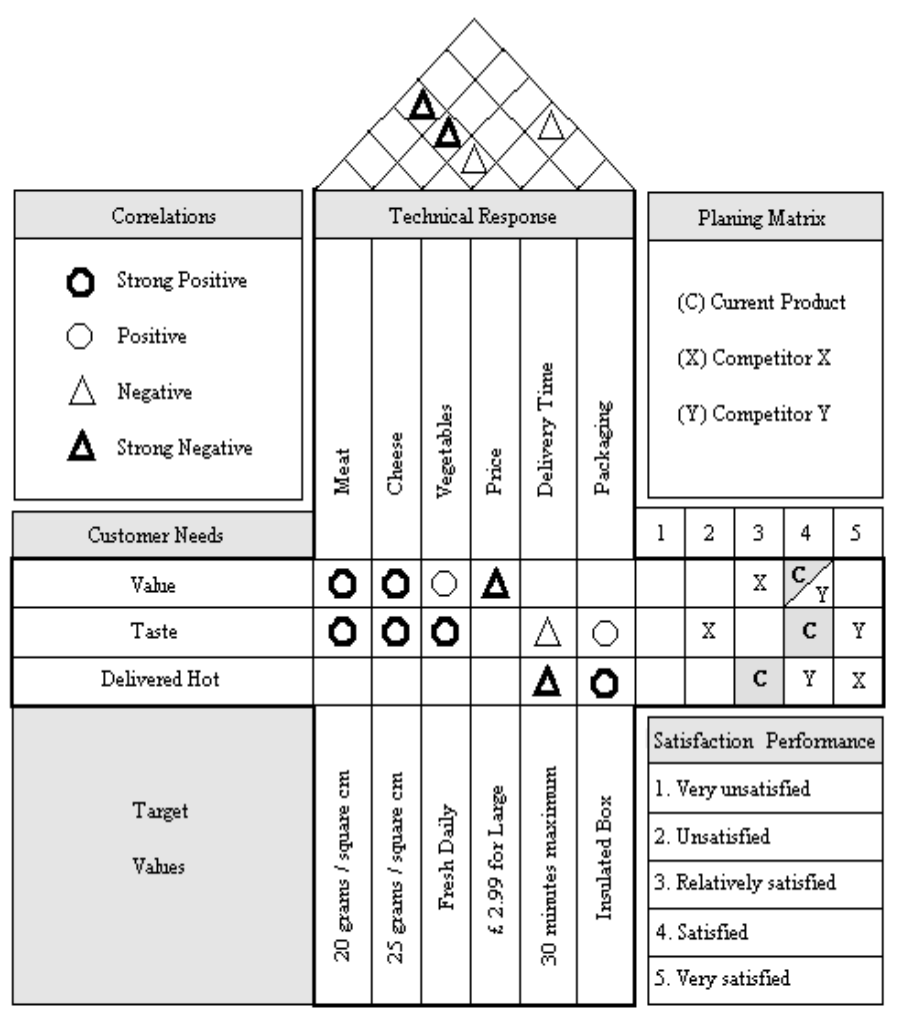

(b) Source: Sower et al (1999)

Figure 1. The House of Quality [1]

Section A has a list of customer needs; Section B contains market data, strategic goal setting for the new product and computations for prioritising the customer needs; Section $\mathrm{C}$ includes information to translate the customer needs into the organisation's technical language; Section D contains the relationship between each customer need and each technical response; Section E (the "roof") assesses the interrelationships between elements of the technical response; Section F contains the prioritisation of the technical responses, information on the competitors and technical targets. Moving on from the HoQ, QFD comprises the building of other matrices that help to make detailed decisions throughout the product development process, however in practice they are rarely used (Cohen, 1995). The main reason for this is that the integration of people required to build the subsequent matrices, will use $80 \%$ of a company's employees (Amos, 1997).

In order to better understand the structure of the $\mathrm{HoQ}$, a brief example is presented. It concerns the improvement of a pizza (Sower et al, 1999); its HoQ is shown in Figure 1(b). As can be seen, the customers want value, taste and the pizzas delivered hot. The current product is superior to competitor $\mathrm{X}$ on two of the three customer requirements, but ranks equal to or below competitor $\mathrm{Y}$ on all three requirements. The purpose of this product redesign project is to make the current product superior to both competitors on all three counts. There is a strong positive correlation between the design requirements of meat and cheese and the customer requirement of value. That means that the more meat and cheese on the pizza, the higher the value to the customer. The roof shows that there is a strong negative correlation between meat and cheese and price, which means that there is a trade-off to be considered. A way to provide a meaty, cheesy pizza at a low price must be found. The bottom of the HoQ shows the target values that the design team has determined must be met to meet the technical responses. These are the specifications for the pizza that will put the current product ahead of its two competitors [1].

QFD uses some principles from Concurrent Engineering in that cross-functional teams are involved in all phases of product development. Each of the four phases in a QFD process uses a matrix to translate customer requirements from initial planning stages through production control (Becker Associates Inc, 2000).

Each phase, or matrix, represents a more specific aspect of the product's requirements. Relationships between elements are evaluated for each phase. Only the most important aspects from each phase are deployed into the next matrix. 

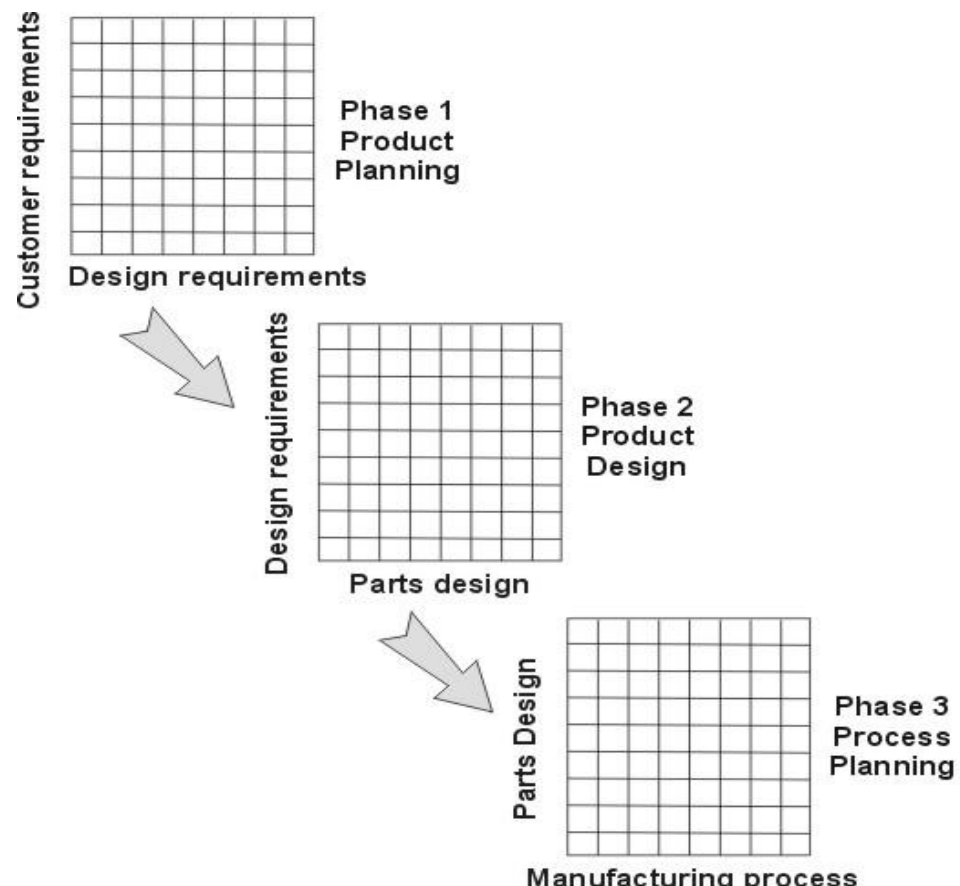

Manufacturing process

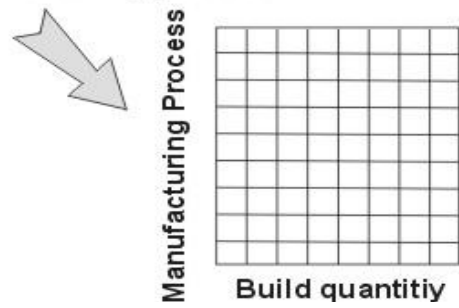

Phase 4

Process

Control

Figure 2. The four phases of traditional QFD [2]

\section{Phase 1, Product Planning:}

Building the House of Quality. Led by the marketing department, Phase 1, or product planning, is also called The House of Quality. Many organizations only get through this phase of a QFD process. Phase 1 documents customer requirements, warranty data, competitive opportunities, product measurements, competing product measures, and the technical ability of the organization to meet each customer requirement. Getting good data from the customer in Phase 1 is critical to the success of the entire QFD process.

\section{Phase 2, Product Design:}

This phase 2 is led by the engineering department. Product design requires creativity and innovative team ideas. Product concepts are created during this phase and part specifications are documented. Parts that are determined to be most important to meeting customer needs are then deployed into process planning, or Phase 3 .

\section{Phase 3, Process Planning:}

Process planning comes next and is led by manufacturing engineering. During process planning, manufacturing processes are flowcharted and process parameters (or target values) are documented.

\section{Phase 4, Process Control:}

And finally, in production planning, performance indicators are created to monitor the production process, maintenance schedules, and skills training for operators. Also, in this phase decisions are made as to which process poses the most risk and controls are put in place to prevent failures. The quality assurance department in concert with manufacturing leads Phase 4[2].

\section{QFD OBJECTIVES}

Table 1 summarises some of the important objectives of QFD. It is important to note that a design project can be considered as a mixture of all objectives. While some trading off is often unavoidable, the way to achieve an outstanding product is to seek to optimize all elements. 
Table 1. Some of the important objectives of QFD [5][6][7][8]

\begin{tabular}{|l|l|}
\hline \multicolumn{1}{|c|}{ Resource } & \multicolumn{1}{c|}{ QFD Objectives } \\
\hline $\begin{array}{l}\text { Vonderembse and Raghunathan } \\
\text { (1997) }\end{array}$ & $\begin{array}{l}\text { To drive long-term improvements in the way new products are } \\
\text { developed in order to create value for customers }\end{array}$ \\
\hline Kathawala and Motwani & (1) Identify the customer \\
(2) Determine what the customer wants \\
(3) Provide a way to meet the customer's desires
\end{tabular}

\section{QFD BENEFITS AND IMPLEMENTATION PROBLEMS}

On the one hand, Hales and Staley (1995) argue that using QFD can result in the development of better products at a price that the customer is willing to pay; moreover, based on its application in different companies, the following advantages and benefits have been reported: Customer satisfaction (Fernandez et al, 1994), reduction in product lead times (Hauser and Clausing, 1988), improved communications through teamwork (Griffin and Hauser, 1992) and better designs (Mehta, 1994). In addition Bicknell and Bicknell (In Chan and $\mathrm{Wu}(2002 \mathrm{a})$ ) reported that tangible benefits that are common when QFD is properly used are: a $30-50 \%$ reduction in engineering changes, 30-50\% shorter design cycles, 20-60\% lower start up costs, and 20-50\% fewer warranty claims.[10]

On the other hand, an empirical study conducted by Martins and Aspinwall (2001) within the United Kingdom (UK), identified many QFD implementation problems among the companies surveyed. The results showed that there was a problem in western companies associated with 'working in teams'. Problems in maintaining a commitment to the methodology and an unsuitable 'organisational culture' were also highlighted. Other aspects, such as 'time consuming', 'costly', and most important, complexity of the methodology, which are commonly mentioned in the literature, were deemed to be only secondary. Govers (1996) declared that most of the problems that companies have to untangle, in order to implement QFD, are related to organisational circumstances like project definition and project management as well as team selection and team building. A critical factor concerning project definition is the "Voice of the Customer" while with respect to project management and team selection, it is essential to have the support of top management and the integration of a team with receptive open-minded members who are willing to challenge established practice. The need for a good facilitator, who knows the method very well and has the social skills to build and to manage a team, was also mentioned[9][11].

Hauser and Clausing (1996) compared start-up and preproduction costs at Toyota auto body in 1977, before QFD, to those costs in 1984, when QFD was well under way. HoQ meetings early on reduced costs by more than $60 \%$. Appendix 10, reinforces this evidence by comparing the number of design changes at a Japanese auto manufacturer using QFD with changes at a US automaker. Also, Hauser and Clausing considered the difference between applying QFD in Japanese companies and not applying QFD in U.S. companies (Appendix 10). As the Appendix shows, Japanese automaker with QFD made fewer changes than U.S. company without QFD. Some benefits of QFD are illustrated in Table 2. 
Table 2: Major Benefits of QFD [13]

\begin{tabular}{|c|c|}
\hline Benefits of QFD & Source \\
\hline $\begin{array}{l}\text { Major reduction in development, time and cost, } \\
\text { shorter design cycle and changes. Significantly } \\
\text { reduces start up problems, times and costs }\end{array}$ & $\begin{array}{l}\text { Ferguson (1990), Stoker (1991), Stauss (1993), Kathawala } \\
\text { and Motwani (1994), Dhalgaard and Kanji (1994), Kenny } \\
\text { (1988), Markland et al (1995, 1988), Hales (1995), Bendell } \\
\text { (1993), Bouchereau and Rowlands (1999, 2000a), Fortuna } \\
\text { (1988), Lockamy and Khurana (1995), Curry and Herbert } \\
\text { (1988), Zairi (1995), Howell (2000) }\end{array}$ \\
\hline Leads to truly satisfy and delighted customer & $\begin{array}{l}\text { Ermer and Kniper (1998), Kathawala and Motwani (1994), } \\
\text { Kenny (1988), Lim and Tang (2000), Stauss (1993), } \\
\text { Howell (2000), Stoker (1991), O' Neal and Lafief (1992), } \\
\text { Markland et al (1995, 1988), Hales (1995), Bendell (1993), } \\
\text { Bouchereau and Rowlands (1999, 2000a), Lockamy and } \\
\text { Khurana (1995), Curry and Herbert (1988), Zairi (1995) }\end{array}$ \\
\hline $\begin{array}{l}\text { Improved Communication } \quad \text { within the } \\
\text { organization. Brings together } \\
\text { teams and encourage team work and participation }\end{array}$ & $\begin{array}{l}\text { Designing for customers satisfaction (1994), Kathawala and } \\
\text { Motwani (1994), Stauss (1993), Dhalgaard and Kanji } \\
\text { (1994), Stoker (1991), Markland et al (1995, 1988), O' } \\
\text { Neal and Lafief (1992), Hales (1995), Bendell (1993), } \\
\text { Fortuna (1988), Zairi (1995) }\end{array}$ \\
\hline $\begin{array}{l}\text { The quality and productivity of service become } \\
\text { more precise in a continual improvement process } \\
\text { and the company can reach world class. }\end{array}$ & $\begin{array}{l}\text { Designing for customers satisfaction (1994), Kanko (1991), } \\
\text { Ermer and Kniper (1998), Howell (2000), Stoker (1991), } \\
\text { Markland et al (1995, 1988), O' Neal and Lafief (1992), } \\
\text { Hales (1995), Bendell (1993), Fortuna (1988), Zairi (1995) }\end{array}$ \\
\hline $\begin{array}{l}\text { QFD clarifies the customer priority for } \\
\text { competitive advantage, Marketing advantage } \\
\text { through improve market acceptability - leading } \\
\text { to increase market share and better reaction to } \\
\text { marketing opportunities }\end{array}$ & $\begin{array}{l}\text { Ferguson (1990), Lim and Tang (2000), Dhalgaard and } \\
\text { Kanji (1994), Stoker (1991), Markland et al (1995, 1988), } \\
\text { Hales (1995), Bendell (1993), Fortuna (1988), Lockamy } \\
\text { and Khurana (1995), Curry and Herbert (1988), Zairi } \\
\text { (1995) }\end{array}$ \\
\hline $\begin{array}{l}\text { Enables one to focus proactively on CR early in } \\
\text { the design stage. Critical items identified for } \\
\text { parameter design and product planning is much } \\
\text { easier to carry out. Also, ensure consistency } \\
\text { between the planning and the production process. }\end{array}$ & $\begin{array}{l}\text { Ferguson (1990), Ermer and Kniper (1998), Kathawala and } \\
\text { Motwani (1994), Stauss (1993), Dhalgaard and Kanji } \\
\text { (1994), O' Neal and Lafief (1992), Zairi (1995) }\end{array}$ \\
\hline
\end{tabular}

QFD is not always easy to implement, and companies have faced problems using QFD, particularly in large, complex systems (Harding et al., 2001). Govers (2001) emphasised that "QFD is not just a tool but has to become a way of management". He also categorized problems of QFD in three groups as: methodological problems, organizational problems and Problems concerning product policy. Table 3, presents some regular problems of QFD.

\begin{tabular}{|l|l|}
\hline \multicolumn{1}{|c|}{ Problems of QFD } & \multicolumn{1}{|c|}{ Source } \\
\hline $\begin{array}{l}\text { If all relational matrixes combined into a single } \\
\text { deployment, the size of each of the combined } \\
\text { relational matrixes would be very large. Completing }\end{array}$ & $\begin{array}{l}\text { Kathawala and Motwani (1994); Dahlgaard and } \\
\text { Kanji (1994); Prasad (2000); Zairi (1995); Dale et } \\
\text { al. (1998); Bouchereau and Rowlands (1999, } \\
\text { QFD late, does not let the changes be implemented. } \\
\text { It takes a long time to develop a QFD chart fully. }\end{array}$ \\
$\begin{array}{l}\text { QFD is a qualitative method. Due to the ambiguity } \\
\text { in the voice of the customer, many of the answers } \\
\text { that customers give are difficult to categorize as as } \\
\text { demands. }\end{array}$ & $\begin{array}{l}\text { Dahlgaard and Kanji (1994); Bouchereau and } \\
\text { Rowlands (1999, 2000a); Designing for customer } \\
\text { satisfaction (1994) }\end{array}$ \\
\hline $\begin{array}{l}\text { It can be difficult to determine the connection } \\
\text { between customer demands and technical } \\
\text { properties. Organizations do not extend the use of }\end{array}$ & $\begin{array}{l}\text { Dahlgaard and Kanji (1994); Dale et al. (1998); } \\
\text { Bouchereau and Rowlands (1999, 2000a) }\end{array}$ \\
\hline $\begin{array}{l}\text { QFD past the product planning stage. } \\
\text { example, in appropriate for all applications. For } \text { automotive industry there are only a } \\
\text { limited number of potential customers; the customer } \\
\text { identifies their needs and the supplier acts to satisfy }\end{array}$ & $\begin{array}{l}\text { Dale et al. (1998); Bouchereau and Rowlands } \\
\text { (1999, 2000a) }\end{array}$ \\
\hline
\end{tabular}


them. For a product of limited complexity and a small supplier base, the effort required to complete a thorough QFD analysis might be justified by customers. Setting target values in the HoQ is imprecise. Strengths between relationships are illdefined.

\section{Table 3. Some regular problems of QFD [13]}

\section{CONCLUSIONS}

In this paper, an attempt was made to demonstrate the capabilities and weaknesses of QFD which has been regarded as one of the most important advanced quality engineering techniques. QFD has been found to have some considerable problems, most of which seem to affect adversely its employment. Examples of some of the most important ones are: ambiguity in the voice of the customer (VoC), managing large HoQ and conflicts between Customers' requirements (CR). In spite of the above problems, there are however a wide range of benefits and advantages associated with using such a customer satisfaction quality design technique, which make it beneficial to designing quality. QFD is a quality design and improvement technique and relatively is closer to the customers than other techniques. Also, QFD can serve as a flexible framework, which can be modified, extended, and be combined with other quality design and improvement techniques. There are still not enough publications about the use of QFD in service areas. However, comparing with other quality design techniques, QFD has the potential to be the most suitable technique for designing quality from customers' point of view. It is believed that the present investigation will provide some good research opportunities; For instance, emphasising on enhancing QFD's capabilities and improving the associated problems with this technique. The flexibility of QFD has facilitated its integration with other advanced quality engineering techniques. However, the following recommendations are made to enhance the capabilities of QFD:

1) More care should be taken to the beginning phases of QFD process (e.g. first house of quality) and new models should be proposed to improve the evaluation of the input data (e.g. customers' requirements), before entering into other HoQs.

2) The effectiveness of QFD should be improved through its integration with other quality engineering techniques which could improve the functioning of traditional QFD at its early stages with respect to: competitive analysis, correlation matrixes, determining critical items, number of phases needed and components of its phases.

3) Enhancements must be designed to take place, with a focus on current problems associated with QFD (e.g. ambiguity in VoC, managing large HoQ and conflicts between CR).

\section{Reference}

[1] D.J. Delgado \& E.M. Aspinwall, (2003) "QFD Methodology and Practical applications - A Review", Proceedings of the Ninth Annual Postgraduate Research Symposium, School of Engineering, The University of Birmingham, 1-5

[2] Akao, Y., ed. (1990). Quality Function Deployment, Productivity Press, Cambridge MA, Becker Associates Inc

[3] Robin Rawlings-Quinn, "QUALITY FUNCTION DEPLOYMENT (QFD): A CASE STUDY",

[4] Dr. Arash Shahin, Quality Function Deployment: A Comprehensive Review, Department of Management, University of Isfahan, Isfahan, Iran

[5] Vonderembse, M.A. and Raghunathan, T.S. (1997) Quality function deployment's impact on product development, International Journal of Quality Science, Vol.2, No.4, pp. 253-271.

[6] Kathawala, Y. and Motwani, J. (1994) Implementing quality function deployment - A system approach, The TQM Magazine, Vol.6, No.6, pp. 31-37.

[7] Franceschini, F. and Rossetto, S. (1995) QFD: the problem of comparing technical/engineering design requirements, Research in Engineering Design, Vol.7, pp. 270-278.

[8] Jagdev, H., Bradley, P., and Molloy, O. (1997) A QFD based performance measurement tool, Computers in Industry, Vol.33, pp. 357-366.

[9] Hales, R. and Staley, D., (1995) “Mix target costing, QFD for successful new products”, Marketing News, 29(1), 18

[10] Chan, L.K. and Wu, M.L., 2002a, Quality Function Deployment: A comprehensive review of its concepts and methods, Quality Engineering, 15(1), 23-35

[11] Chan, L. K. and Wu, M. L., 2002b, Quality function deployment: A literature review, European Journal of Operational Research, 143(2002), 463-497

[12] Ferguson, I. (1990) Process design, TQM Magazine, Vol.2, No.2, April, 103-108.

[13] Adiano, C. and Roth, A.V. (1994) Beyond the house of quality: Dynamic QFD, Benchmarking: An International Journal, Vol.1, No.1, 25-37.

[14] Akao, Y. (1990) Quality function deployment (QFD) - Integrating customers' requirements into product design, English translation copyright, Productivity Press, USA.

[15] Akao, Y., Ono, S., Harada, A., Tanaka, H., Iwasawa, K. (1983) Quality deployment including cost, reliability, and technology, Quality, Vol.13, No.3, 61-77.

[16] American Supplier Institute (1994) Quality Function Deployment (service QFD): 3-day workshop, ASI Press, Dearborn, MI.Antonacopoulou, E. and Kandampully, J. (2000) Alchemy: The transformation to service excellence, The Learning Organization, Vol.7, No.1, 13-22.

[17] Azzolini, M. and Shillaber, J. (1993) Internal service quality: Winning from the inside out, Quality Progress, November, 75-78. 
[18] Barnett, W.D. and Raja, M.K. (1995) Application of QFD to the software development process, International Journal of Quality and Reliability Management, Vol.12, No.6, 24-42.

[19] Bendell, T. (1993) Quality: Measuring and monitoring, The Century Business, UK, 150-164.Betts, M. (1990) QFD integrated with software engineering, Transactions of The Second Symposium on Quality Function Deployment, Novi, MI, 442-459.Bicheno, J. (1994) The Quality 50: a guide gurus, tools, wastes, techniques and systems, PICSIE Books.Bier, I.D. and Cornesky, R. (2001) Using QFD to construct a higher education curriculum, Quality Progress, April, 64-68.Bode, J. and Fung, R.Y.K. (1998) Cost engineering with quality function deployment, Computers and Industrial Engineering, Vol.35, No. 3/4, 587-590.

[20] Bouchereau, V. and Rowlands, H. (1999) Analytical approaches to QFD, Manufacturing Engineer, Vol.78, No.6, December, 249254.

[21] Bouchereau, V. and Rowlands, H. (2000a) Methods and techniques to help quality function deployment (QFD), Benchmarking: An International Journal, Vol.7, No.1, 8-19.

[22] Bouchereau, V. and Rowlands, H. (2000b) Quality function deployment: The unused tool, Engineering Management Journal, Vol.10, No.1, February, 45-52.

[23] Brusch, M., Trilk, H., Dinse, C. and Treppa, A. (2001) Gemeinsam Starker - Integration von quality function deployment und target costing, Qualitat und Zuverlassigkeit, Vol.46, No.10, 1306-1321.

[24] Burchill, G. and Fine, C.H. (1997) Time versus market orientation in product concept development: Empirically-based theory generation, Management Science, Vol.43, No.4, 465-478.

[25] Chan, L.K. and Wu, M.L. (1998) Prioritizing the technical measures in quality function deployment, Quality Engineering, Vol.10, No.3, 67-479.

[26] Chan, L.K. and Wu, M.L. (2002) Quality function deployment: A literature review, European Journal of Operational Research, Article In Press, Uncorrected Proof, Available online 1 April, 1-35.Cheng Lim, P., Aquilano, N.J., and Jacobs, F.R. (1999) An innovative framework for health care performance measurement, Managing Service Quality, Vol.9, No.6, 423-433.

[27] Chow-Chua, C. and Komaran, Raj (2002) Managing service quality by combining voice of the service provider and voice of their customers, Managing Service Quality, Vol.12, No.2, 77-86.

[28] Clausing, D. and Pugh, S. (1991) Enhanced quality function deployment, Proceedings of The Design and Productivity International Conference, February 6-8, Honolulu, HI.Cohen, L. (1995) Quality function deployment - How to make QFD work for you, Addison Wesley Longman Inc., USA.Conti, T. (1989) Process management and quality function deployment, Quality Progress, December, 45-48.Cook, H.E. and Wu, A. (2001) On the valuation of goods and selection of the best design alternative, Research in Engineering Design, Vol.13, No.1, 42-54.

[29] Cristiano, J.J., Liker, J.K., and White, Ch.C. (2000) Customer-driven product development through quality function deployment in the U.S. and Japan, Journal of Production Innovation Management, Vol. 17, No.4, 286-308.

[30] Crow, K. (1996) Customer-focused development with QFD, 8 pages.Curry, A. and Herbert, D. (1998) Continuous improvement in public services: a way forward, Managing Service Quality, Vol.8, No.5, 339-349.

[31] Dahlgaard, K. and Kanji (1994) Break down barriers between departments, Advances in Total Quality Management, 81-89.Dale, B., Boaden, R., Wilcox, M., and McQuarter, R. (1998) Use of quality management techniques and tools: An examination of some key issues, International Journal of Technology Management, Vol.16, No.4-6, 305-325.

[32] Dean, E.B. (1998) Quality function deployment: From the perspective of competitive advantage. Designing for customer satisfaction (1994) Management Decision, Vol.32, No.5, 37-38.

[33] Dube, L., Johnson, M.D. and Renaghan, L.M. (1999) Adapting the QFD approach to extended service transactions, Production and Operations Management, Vol.8, No.3, 301-317.

[34] Ellis, R.L. (1998) QFD: A tool to sharpen measurement, Public Manager, Vol.27, No.2, 33-36.

[35] Ermer, D.S. and Kniper, M.K. (1998) Delighting the customer: quality function deployment for quality service design, Total Quality Management, Vol.9, No.4/5, S86-S91.

[36] Evans, J.R. and Lindsay, W.M. (1993) The management and control of quality, West Publishing Company, Second edition, USA, 150-166.Evbuomwan, N.F.O., Sivalognathan, S. and Jebb, A. (1994) Concurrent design with design function deployment, Proceedings of the Second International Conference on Concurrent Engineering and Electronic Design Automation, 7-8 April, UK.

[37] Ferguson, I. (1990) Process design, TQM Magazine, Vol.2, No.2, April, 103-108.

[38] Field, S.W. and Swift, K.G. (1996), Effecting a quality change: an engineering approach, Arnold, UK, 56.Garside, J.A. and Appleton, E. (1996) QFD - Will it do for new product introduction what JIT did for manufacture?, Advanced Manufacturing Processes-Systems and Technologies (AMPST 96), 753-765.Hallberg, N., Timpka, T., Eriksson, H. (1999) The medical software quality deployment method, Methods of Information in Medicine, Vol.38, No.1, 66-73.

[39] Hales, R., Lyman, D. and Norman, R. (1994) QFD and the expanded house of quality, Quality Digest, February. Jagdev, H., Bradley, P., and Molloy, O. (1997) A QFD based performance measurement tool, Computers in Industry, Vol.33, 357-366.

[40] Kathawala, Y. and Motwani, J. (1994) Implementing quality function deployment - A system approach, The TQM Magazine, Vol.6, No.6, 31-37.

[41] Kauffmann, P., Unal, R., Fernandez, A. and Keating C. (2000) A model for allocating resources to research programs by evaluating technical importance and research productivity, Engineering Management Journal, Vol.12, No.1, 5.

[42] Leo Lo, T.; Kolence, Kenneth W. (1994) House of quality and service management, CMG Proceedings, Vol.1, pp. 521-532.

[43] Lim, P.Ch. and Tang, N.K.H. (2000), The development of a model for total quality health care, Managing Service Quality, Vol.10, No.2, 103-111.

[44] Liu, X.F. (2001) Software quality function deployment, IEEE Potentials, Vol.19, No.5, 14-16.

[45] Locascio, A. and Thurston, D.L. (1993) Multiattribute design optimization using QFD, Proceedings of the 2nd Industrial Engineering Research Conference, Industrial Engineering and Management Press.Lockamy III, A. and Khurana, A. (1995) Quality function deployment: total quality management for new product design, International Journal of Quality \& Reliability Management, Vol.12, No.6, 73-84

[46] Mallon, J.C. and Mulligan, D.E. (1993) Quality function deployment - A system for meeting customers' needs, Journal of Construction Engineering and Management, Vol.119, September, 516-531.

[47] Markland, R.E., Vickery, Sh.K., and Davis, R.A. (1995) Operations management - Concepts in manufacturing and services, West Publishing Company, USA, 164-171.Markland, R.E., Vickery, Sh.K., Davis, R.A., and Sounderpandian, J. (1998) Operations management - Concepts in manufacturing and services, South-Western College Publishing, Second edition, USA, 179.Martins, A. and Aspinwall, E.M. (2001), Quality function deployment: an empirical study in the UK, Total Quality Management, Vol.12, No.5, 575-588.

[48] Masud, A.S.M. and Dean, E.B. (1993) Using fuzzy sets in quality function deployment, Proceedings of the Second Industrial Engineering Research Conference, Industrial Engineering and Management Press.Matsuda, L.M., Evora, Y.D. and Boan, F.S. 
(2000) Quality function deployment method - QFD - in the planning of nursing service, Revista Brasileira de Enfermagem, Vol.8, No.5, 97-105.

[49] Matzler, K. and Hinterhuber, H.H. (1998) How to make product development projects more successful by integrating Kano's model of customer satisfaction into quality function deployment, Technovation, Vol.18, No.1, 25-38.

[50] Mazur, G.H. (1993) QFD for Service Industries, from Voice of Customer to Task Deployment, The Fifth Symposium on Quality Function Deployment, Novi, Michigan, Japan Business Consultants, Ltd., 485- 503.Menks, D., Ahmed, A. and Fu, K. (2000) Quality function deployment, SENG 613 Team Work, Software Engineering Research Network, University of Galgary, Fourth of December.Mersha, T. and Adlakha, V. (1992) Attributes of service quality: the consumers' perspective, International Journal of Service Industry Management, Vol.3, No.3, 34-45.

[51] Nakui, S.C. (1991) Comprehensive QFD system, Transactions of The Third Symposium on Quality Function Deployment, June 2425, Novi, MI, 137-152.O’Neal, Ch.R. and Lafief, W.C. (1992) Maketing's lead role in total quality, Industrial Marketing Management, Vol.21, No.2, May, 133 143.Ouyang, S., Fai, J., Wang, Q. and Kim, J. (1997) Quality function deployment, Department of Computer Science, University of Calgary, Partovi, F.Y. (1999) A quality function deployment approach to strategic capital budgeting, Engineering Economist, Vol.44, No.3, 239- 260.

[52] Partovi, F.Y. (2001) An analytic model to quantify strategic service vision, International Journal of Service Industry Management, Vol.12, No.5, 476-499.

[53] Prasad, B. (1993) Product planning optimization using quality function deployment, AI in Optimal Design and Manufacturing, Edited by Z. Dong, series editor M. Jamshidi, Englewood, NJ, Prentice Hall, 117- 152.Prasad, B. (1996) Concurrent Engineering Fundamentals, Integrated Product and Process Organization, Vol.1.

[54] Prasad, B. (1998a) Review of QFD and related deployment techniques, Journal of Manufacturing Systems, Vol.17, No.3, 221-234.

[55] Prasad, B. (1998b) Synthesis of market research data through a combined effort of QFD, value engineering and value graph techniques, Quantitative Market Research: An International Journal, Vol.1, No.3, 156- 172.

[56] Pun, K.F., Chin, K.S., and Lau, H. (2000) A QFD/hoshin approach for service quality deployment: A case study, Managing Service Quality, Vol.10, No.3, 156-169.

[57] Rajala, M. and Savolainen, T. (1996) A framework for customer oriented business process modelling, Computer Integrated Manufacturing System, Vol.9, No.3, 127-135.

[58] Reich, Y. (1995) Computational quality function deployment in knowledge intensive engineering, Proceedings of the IFIP WG5.2 First Workshop on Knowledge Intensive CAD, Helsinki, Finland.Ross, Ph.J. (1998) The role of Taguchi methods and design of experiments in QFD, Quality Progress, June, 41-47.Scheurell, D.M. (1992) Concurrent engineering and the entire QFD process: one year after start-up of a new mill, Transactions of the Fifth Symposium on Quality Function Deployment, Novi, MI: QFD Institute.Schmidt, R. (1997) The implementation of simultaneous engineering in the stage of product concept development: A process oriented improvement of quality function deployment, European Journal of Operational Research, Vol.100, No.2, 293-314.

[59] Schubert, M.A. (1989) Quality function deployment: A means of integrating reliability throughout development, Proceedings of The Society of American Value Engineers Conference, 93-98.Shen, X.X., Tan, K.C., and Xie, M. (2000) An integrative approach to innovative product development using Kano's model and QFD, European Journal of Innovation Management, Vol.3, No.2, 91-99.

[60] Shin, J.S. and Kim, K.J. (2000) Effect and choice of the weighting scale in QFD, Quality Engineering, Vol.12, No.3, 347-356.

[61] Smith, J.A. and Angeli, I.I. (1995) The use of quality function deployment to help adopt a total quality strategy, Total Quality Management, Vol.6, No.1, 35-44.

[62] Sower, V.E., Savoie, M.J., and Renick, S. (1999) An introduction to quality management and engineering, Prentice-Hall, Inc., USA, 45.Stauss, B. (1993) Service problem deployment: Transformation of problem information into problem prevention activities, International Journal of Service Industry Management, Vol.4, No.2, 41-62.

[63] Stocker, G.D. (1991) Quality function deployment: listening to the voice of the customer, American Production and Inventory Control Society - The Performance Advantage 1, September, 44-48.Storen, S. (1997) Sustainable product design - Is there more to it than science, systems and computers?, Creativity and Innovation Management, Vol.6, No.1, 3-9.

[64] Stuart, F.I. and Tax, S.S. (1996) Planning for service quality: an integrative approach, International Journal of Service Industry Management, Vol.7, No.4, 58-77.

[65] Swanson, R. (1993) Quality benchmark deployment, Quality Progress, December, 81-84.Taguchi, G. and Clausing, D.P. (1990) Robust quality. Harvard Business Review, Vol. 68, 65-75.

[66] Taguchi, S. (1987) Taguchi Methods and QFD: HOWs and WHYs for Management, American Supplier Institute Press, Dearborn, MI. Tottie, M. and Lager, T. (1995) QFD: Linking the customer to the product development part, R\&D Management, Vol.25, 257267.

[67] Trappey, C.V.,Trappey, A.J.C. and Hwang, S.J. (1996) A computerized quality function deployment approach for retail services, Computers and Industrial Engineering, Vol.30, No.4, 611-622.

[68] Ur Rahman, Sh. (1995) Product development stages and associated quality management approaches, The TQM Magazine, Vol.7, No.6, 25-30.

[69] Vairaktarakis, G.L. (1999) Optimization tools for design and marketing of new/improved products using the house of quality, Journal of Operations Management, Vol.17, 645-663.

[70] Verma, D., Chilakapati, R. and Fabrycky, W.J. (1998) Analysing a quality function deployment matrix: An expert system-based approach to identify inconsistencies and opportunities, Journal of Engineering Design, Vol.9, No.3, 251-261.

[71] Vonderembse, M.A. and Raghunathan, T.S. (1997) Quality function deployment's impact on product development, International Journal of Quality Science, Vol.2, No.4, 253-271.

[72] Witter, J., Clausing, D., Laufenberg, L., De Andrade, R.S. (1995) Reusability - The key to corporate agility: Its integration with enhanced quality function deployment, World Class Design to Manufacture, Vol.2, No.1, 25-33.

[73] Yilmaz, M.R. and Chatterjee, S. (1997) Deming and the quality of software development, Business Horizons, Vol.40, No.6, 51-58.

[74] Xie, M., Goh, T.N., and Wang, H. (1998) A study of sensitivity of "customer voice" in QFD analysis International Journal of Industrial Engineering, Vol.5, No.4, 301-307.

[75] Zairi, M. (1995) Quality function deployment - A main pillar for successful total quality management and product development, International Journal of Quality and Reliability Management, Vol.12, No.6, 9- 23.

[76] Zhang, Y., Wang, H.P. and Zhang, C. (1999) Green QFD-II: A life cycle approach for environmentally consious manufacturing by integrating LCA and LCC into QFD matrixes, International Journal of Production Research, Vol.37, No.5, 1075-1091.

[77] Zhao, X., Bai, Ch. and Hui, Y. V. (2002) An empirical assessment and application of SERVQUAL in a Mainland Chinese department store, Total Quality Management, Vol.13, No.2, 241-254.

[78] Zultner, R.E. (1994) Software quality function deployment: The first five years - Lessons learned, ASQC 48th Annual Quality Congress Proceedings, 783-793. 